\title{
WARREN BARTLETT WALSH, 1909-1979
}

Warren Bartlett Walsh, professor emeritus of Russian history at Syracuse University, died June 9, 1979 in his home in Dewitt, New York. Professor Walsh pursued his undergraduate degree at Tufts University and his doctorate at Harvard University, working under the direction of Professors W. L. Langer and M. M. Karpovich. All of his teaching and scholarly work was done at Syracuse University, where he joined the Department of History in 1935. Professor Walsh was an inspiring lecturer and an excellent teacher. Despite his high standards and his rugged demands, his undergraduate courses in Russian history always attracted large enrollments. His graduate students knew him as an exacting master who imparted sound historical training, but who also urged his students to be aware of and profit by the findings of other scholars in fields such as anthropology and social psychology.

Professor Walsh organized the Board of Russian Studies at Syracuse University and served as its chairman for many years. During World War II, he participated in a famous Rumor Clinic along with the distinguished social psychologist, Floyd Allport. As a result, when Russia became involved in the war, Walsh was widely sought after as a speaker on Soviet affairs.

He served as chairman of the Department of History at Syracuse from 1961 to 1967, at a time of expansion and significant change for the department. Professor Walsh served for a time as director of political studies at the National War College in Washington, D.C. Later he taught and lectured at many of the advanced colleges of the various armed services. The Department of the Army awarded him the highest decoration which can be conferred on a civilian.

Professor Walsh was a prolific historian, having contributed many articles to professional journals. He is probably best known for his widely used and very successful Readings in Russian History, which went through many editions. He also wrote a highly successful book, Russia and the Soviet Union.

A true son of New England, Professor Walsh loved the Maine coast where he had a summer home and spent many summers completing some of his best writing. He is survived by his wife, Elizabeth, three daughters, and several grandchildren. $\mathrm{He}$ will be fondly remembered by over a score of candidates who completed their doctoral work under his direction.

\section{Kenneth I. Dailey} Xenia, Ohio

\section{VLADIMIR WEIDLE, 1896-1979}

Vladimir Vasil'evich Weidlé, Chevalier de l'Ordre du Mérite Artistique et Littéraire, art historian, critic, essayist, and poet, was born in St. Petersburg in 1896 . He graduated in history from the University of St. Petersburg in 1916. From 1916 to 1918, he lectured in history, and taught history of West European medieval art from 1921 to 1924 at the same university. In 1924, he emigrated to Paris, where he contributed to Russian literary journals and newspapers. He had begun to publish long before his move to Paris, however. His article about Marcel Proust appeared in the St. Petersburg journal The Contemporary West, two poems and several critical reviews appeared in the journal The Russian Contemporary, and his first literary essay on Alexander Blok and his poem "Oda" appeared in the almanac Tomorrow (Berlin, 1923).

During the period 1932-52, Weidlé was professor of Christian art and Western religious history at the Russian Theological Academy in Paris. He served as director of programing at Radio Free Europe in Munich from 1953 to 1958. Later he was appointed professor at the European College in Brugge (Belgium). He lectured at 